\title{
Üniversite Uyum Ölçeğinin Geliştirilmesi: Geçerlik ve Güvenirlik Çalışmaları*
}

\section{Development of University Adjustment Scale: Validity and Reliability Studies}

\author{
Seda SEVİNÇ TUHANIOĞLU**, Cem Ali GIZZIR ${ }^{* * *}$
}

• Geliş Tarihi: 01.04.2019 • Kabul Tarihi: 23.09.2019 • Çevrimiçi Yayın Tarihi: 23.09.2019

\section{$\ddot{O} \mathbf{z}$}

$\mathrm{Bu}$ çalışmada, üniversite öğrencilerinin üniversiteye uyum düzeylerini dört temel boyut (akademik, sosyal, kişisel-duygusal ve kurumsal) odağında belirlemeye yönelik geliştirilen Üniversiteye Uyum Ölçeğinin (ÜUÖ) psikometrik özelliklerinin incelenerek geçerlik ve güvenirliğinin sınanması amaçlanmaktadır. Araştırmanın iki farklı çalışma grubunu, bir devlet üniversitesinin çeşitli fakültelerinde öğrenim görmekte olan 712 (430 kadın, 282 erkek) ve 418 (261 kadın, 157 erkek) birinci sınıf üniversite öğrencisi oluşturmaktadır. Bu çalışmada, geliştirilen ölçme aracının yapı geçerliğini incelemek amacıyla açıklayıcı ve doğrulayıcı faktör analizi yöntemlerinden yararlanılmıştır. Analiz sonuçları, ölçeğin, 45 maddeyi içeren dört faktörlü bir yapı sergilediğini ortaya koymuştur. Benzer ölçekler geçerliği kapsamında yapılan analiz sonucunda da ÜUÖ ile Üniversite Yaşamı Ölçeği arasında yüksek düzeyde bir ilişki bulunmuştur. Ölçeğin Cronbach alfa ile belirlenen iç tutarlık katsayıları akademik uyum için .92, sosyal uyum için .88 , kişisel-duygusal uyum için .91 , kurumsal uyum için .89 ve toplam ölçek puanı için .94 olarak hesaplanmıştır. ÜUÖ'nün test tekrarı güvenirlik katsayılarının ise .76 (kişisel uyum) ile .88 (kurumsal uyum) arasında değiştiği belirlenmiştir. Sonuç olarak, üniversite öğrencileri kapsamında geliştirilen dört faktörlü ÜUO'nün hem kuramsal hem de istatistiksel olarak geçerlik ve güvenilirlik ölçütlerini oldukça iyi düzeyde karşıladığı belirlenmiş̧ir.

Anahtar sözcükler: üniversiteye uyum, üniversite öğrencileri, geçerlik, güvenirlik.

Atıf:

Sevinç Tuhanioğlu, S. ve Gizir, C. A. (2020). Üniversite uyum ölçeğinin geliştirilmesi: Geçerlik ve güvenirlik çalışmaları. Pamukkale Üniversitesi Eğitim Fakültesi Dergisi, 49, 67-87. doi: 10.9779/pauefd.547409

\footnotetext{
*Bu çalışma birinci yazarın, ikinci yazar danışmanlığında yaptığı doktora tez çalışmasından üretilmiştir.

**Dr., Mersin Üniversitesi, Psikolojik Danışma ve Rehberlik Merkezi, seda_sevinc@hotmail.com https://orcid.org/0000-0001-9009-2276

***Doç Dr., Mersin Üniversitesi, Eğitim Fakültesi, Eğitim Bilimleri Bölümü, cagizir@mersin.edu.tr https://orcid.org/0000-0002-1928-781X
} 


\begin{abstract}
The main purpose of the present study is to develop and test the psychometric properties of the University Adjustment Scale (UAS). There were two participant-groups in the study compromising of 712 (430 female, 282 male) and 418 (261 female, 157 male) first-year undergraduate students enrolled in various faculties of a public university in Turkey. The construct validity of the scale was tested by using exploratory and confirmatory factor analyses. The result of the analyses showed that the UAS constituted from four factors including, "academic adjustment", "social adjustment", "personal-emotional adjustment", and "institutional adjustment". Criterion validity study yielded a high correlation between UAS and University Life Scale. The Cronbach alpha coefficients of the four factors were .92 for academic adjustment, .88 for social adjustment, .91 for emotional adjustment, .89 for institutional adjustment, and .94 for the full scale. The test-retests (three weeks interval) reliability coefficients of the factors were also changed between .76 (emotional adjustment) and .88 (institutional adjustment). Consequently, the study findings indicated that the UAS has a very good psychometric properties for using to assess the university adjustment levels of first-year university students.
\end{abstract}

Keywords: university adjustment, university students, validity, reliability

\title{
Cited:
}

Sevinç Tuhanioğlu, S., \& Gizir, C. A. (2020). Development of university adjustment scale: Validity and reliability studies. Pamukkale Üniversitesi Eğitim Fakültesi Dergisi, 49, 67-87. doi: 10.9779/pauefd.547409 


\section{Giriș}

Günümüzde çok farklı alanlarda sıklıkla kullanılan uyum (adjustment) kavramı, psikolojik açıdan, bireylerin sahip oldukları gereksinimlerin içinde bulundukları çevreyle kurulan etkileşimler yoluyla doyuma ulaştırılmasına vurgu yapmaktadır. Başka bir ifadeyle, durumlar ve koşullar yani çevre değiştikçe bireyin uyum sağlama kapasitesi ortaya çıkmaktadır. Birey, uyum sağlama kapasitesi sayesinde koşullar değişse de değişen koşullar içerisinde kendi gereksinimlerini karşılama yollarını oluşturabilmekte ve çevreyle olan ahenkli ilişkisini devam ettirebilmektedir (Perls, 1969). Bu bağlamda uyum süreci, bireyin içinde bulunduğu fiziki ve sosyal çevrede yaşamda kalabilmek adına göstermiş olduğu çabaların tümünü ifade etmektedir (Monroe, 2009).

Bu bakış açısıyla ele alındığında, birçok genç yetişkinin yaşamında önemli değişimlerden biri olan liseden üniversiteye geçiş sürecinin sağl1klı bir şekilde tamamlanabilmesinde üniversite öğrencilerin uyum sağlama kapasitelerinin niteliği önem kazanmaktadır (Baker ve Siryk, 1984; 1986; Tinto, 1988). Bununla birlikte, ilgili alanyazında, bilinen ya da tanınan bir çevreden ayrılan öğrencilerin yeni bir akademik ve sosyal çevreyle karşılaştıkları kritik bir süreç olarak tanımlanan üniversitenin ilk yılı (Clinciu, 2013; Gall, Evans ve Bellerose, 2000), üniversite öğrencileri açısından, uyum sürecinin en zorlu dönemi olarak ifade edilmektedir (Paul ve Brier, 2001). Bu bağlamda, öğrencilerin üniversite çevresini tanımaya, akademik, kişisel, sosyal ve mesleki beklentilerini anlamaya ve olası sorunları çözmeye çalıştıkları bu süreç, günümüzde, üniversite yaşamına uyum kavramı çerçevesinde ele alınmaktadır.

Tarihsel gelişimi incelendiğinde, alanyazında yer alan çalışmaların genel olarak üniversiteye uyumu bir süreç değişkeni (akademik, sosyal ve duygusal alanlarda büyüme ve değişme, üniversite yaşamının gerekliliklerini karşılama) olarak ele aldıkları (Awang, Kutty ve Ahmad, 2014; Feldt, Graham ve Dew, 2011; Julia ve Veni, 2012) ya da davranışsal çıktıları olan bir sonuç değişkeni (akademik başarı, psikolojik iyilik hali, yabancılaşma vb.) (Boulter, 2002; Cooke, Bewick, Barkham, Bradley ve Audin, 2006; Hersh ve Hussong, 2006; Klomegah, 2006; Trockel, Barnes ve Egget, 2000) olarak değerlendirdikleri gözlemlenmektedir. Diğer yandan, 1980'li yıllardan bu yana üniversite yaşamına uyum, çok boyutlu ve bileşik bir kavram olarak nitelendirilmektedir (Baker, McNeil ve Siryk, 1985; Baker ve Siryk, 1984; 1986). Akademik beklenti ve talepleri karşılama, öğrenci, öğretim elemanı ve üniversite personeliyle sağlıklı ilişkiler kurma, yerleşkedeki etkinliklere katılarak üniversitenin ders dışı yaşamından doyum sağlayabilme ve öznel psikolojik gereksinimleri karşılayabilme gibi çok çeşitli ölçütlerin yer aldığ bu yaklaşımda, üniversite yaşamına uyum temel olarak dört boyutta (akademik uyum, sosyal uyum, kişisel-duygusal uyum ve kurumsal uyum) ele alınmaktadır (Baker ve Siryk, 1984; 1986). İlgili alanyazında da son 20 yılda yürütülen çeşitli çalışmalarda (Ayhan, 2005; Fassig, 2003; Katz ve Somers, 2017; Lidy ve Kahn, 2006; Rahat, 2014; Salami, 2011; Tuna, 2003; Yalım, 2007) bu çok boyutlu yaklaşımın hâkim olduğu görülmektedir. Dolayısıyla, üniversitenin ilk yılında hatta ilk döneminde birçok faktörün birlikte etkileşiminden dolayı çok çeşitli kişisel ve sosyal kaynakların kullanılmasına gereksinim duyulan ve oldukça karmaşık bir süreç olan üniversite yaşamına uyumu (Clinciu, 2013) şekillendiren bu dört temel boyutun yakından incelenmesi gerekmektedir.

Üniversiteye uyum sürecinin önemli bir boyutu olarak akademik uyum, en temelde, Tinto'nun (1993) tanımladığı çerçevede öğrencilerin üniversitenin akademik çevresine ve bu 
çevrenin gerekliliklerine "uygunluk" gösterebilmeleri ile ilişkili bir kavramdır. Bu bağlamda akademik yaşama yönelik tutum ve algıları içeren akademik uyum, öğrencilerin öğrenmeye açık olmaları ve başarılı bir şekilde akademik yükümlülükleri yerine getirmeleri ile üniversitenin akademik çevresinden doyum almaları olarak tanımlanmaktadır (Baker ve Siryk, 1984). Bu yönüyle akademik uyum, üniversite öğrenimine başlayan öğrencilerin karşlaştıkları yeni eğitimsel gerekliliklerle baş etme düzeyleri olarak değerlendirilebilir ve en temelde akademik uyumun öğrenci ile üniversitenin akademik çevresinin uygunluğunu gerektirdiği ifade edilebilir.

Üniversiteye uyumun bir diğer boyutu olarak ele alınan sosyal uyum, öğrencilerin üniversite yaşamında başarılı olup öğrenimlerine devam edebilmeleri açısından en az akademik uyum kadar önemli görülmekte ve öğrencilerin üniversitenin sosyal yaşamına katılmaları, sağlıklı ilişkiler kurarak üniversitenin sosyal yaşamının bir parçası gibi hissetmeleri (sosyal bütünleşme) ve en nihayetinde üniversitedeki sosyal yaşamdan doyum alabilmeleri olarak tanımlanmaktadır (Tinto,1993). Benzer şekilde Baker ve Siryk'in $(1984 ; 1986)$ çalışmalarında üniversiteye uyumla ilişkili önemli bir boyut olarak ele alınan sosyal uyum, öğrencilerin üniversite yerleşkesinde yeni ilişkiler geliştirerek çeşitli ders dışı etkinliklere katılmalarını ve üniversitenin sosyal çevresinden keyif almalarını nitelendirmektedir. Bu bakış açısına göre üniversite öğrenimine yeni başlayan öğrencilerin sosyal destek ağları oluşturabilmeleri, üniversitenin sosyal destek sistemlerini kullanabilmeleri, sosyal özgürlüklerini yönetebilmeleri ve yeni arkadaşlıklar kurup bu arkadaşlıkları sağlıklı bir şekilde devam ettirebilmeleri sosyal uyumun en önemli belirleyicileri olmaktadır (Freeman, Anderman ve Jensen, 2007).

Üniversite yaşamına uyumun bir diğer alanı olarak tanımlanan kişisel-duygusal uyum, genel olarak öğrencilerin psikolojik süreçleriyle bağlantılı olarak tanımlanmaktadır. Nitekim Baker ve Siryk (1984) kişisel-duygusal uyumu, fiziksel ve duygusal iyilik hali odağında öğrencilerin üniversite ortamında kendilerini güvende hissedip, yoğun duygularla ve günlük stresle baş edebilmeleri ve dolayısıyla daha az somatik yakınmalarda bulunmaları çerçevesinde ele almaktadırlar. İlgili alanyazında da üniversiteye geçiş süreci, genellikle stres dolu bir deneyim olarak değerlendirilmekte ve bu stresli süreci etkili bir şekilde yönetemeyen birinci sınıf öğrencilerinin özgüven eksikliği, kaygı ve depresyon gibi çeşitli problemler yaşadıkları belirtilmektedir (Dyson ve Renk, 2006; Lau, 2003; Rienties vd., 2011; Tuna, 2003).

Üniversiteye uyumun sonuncu boyutu olarak ele alınan kurumsal uyum ise öğrencinin içinde bulunduğu kurum (üniversite) ile amaç ortaklığı yapabilmesi ve kendisini bu kurumun bir parçası hissederek üniversiteden doyum almasını kapsamaktadır (Baker ve Siryk, 1984). Elbette ki öğrencilerin kendilerini üniversitenin bir parçası olarak hissetmeleri, onların üniversitedeki akademik ve sosyal deneyimleri ile yakından ilgilidir (Tinto, 1993). Buna göre, üniversitenin akademik ve sosyal yaşamıyla bütünleşebilmiş ve içinde bulunduğu kurumun kültürünü kendi kültürü haline getirebilmiş öğrenciler, üniversiteye bağlllık geliştirerek kendilerini o üniversitenin bir parçası olarak tanımlayabilmektedirler (Tuna, 2003). Benzer şekilde Julia ve Veni (2012), öğrencilerin kayıtlı oldukları üniversitenin vizyon ve misyonunun özünü oluşturan norm ve değerlere uygunluk gösterme düzeylerini üniversiteye uyum olarak tanımlamaktadırlar. $\mathrm{Bu}$ noktada kurumsal uyum, bütünleşme ve kuruma aidiyet çerçevesinde ele alındığında, özellikle öğretim elemanlarıyla sınıf-içi ve sınıf-dışı etkileşimler, akran ilişkileri ve yerleşkedeki etkinliklere katılımın ön plana çıkan konular olduğunu söylemek oldukça olasıdır. Dolayısıyla, akademik ve sosyal uyumla ilişkili olan birçok değişkenin kurumsal uyum ve bağlanma ile 
ilişkili olduğu görülmektedir. Ayrıca, kurumun yapısal özellikleri (büyüklüğü, barındırdığı programları, fiziksel olanakları, yerleşkesinin fiziksel özellikleri vb.) ile öğrencilerin sahip oldukları kişisel özelliklerin de kuruma bağlanmayı ve dolayısıyla üniversiteye uyumu etkilediği belirtilmektedir (Pasceralla ve Terenzini, 2005).

Türkiye'deki yükseköğretim kurumlarının öğrenci profilleri (Gizir vd., 2010) ile öğrencilerin üniversiteye uyum süreçlerini (Tuna, 2003) yukarıda sözü edilen dört boyut (akademik, sosyal, kişisel-duygusal ve kurumsal) üzerinden incelemeye yönelik sınırlı sayıda çalışmaya rastlanıldığından, geçmişten günümüze Türkiye'deki üniversite öğrencilerinin nasıl bir değişim ve gelişim içinde oldukları tam olarak bütüncül bir yaklaşımla ele alınamamaktadır (Gizir, 2014). Bu noktada, öğrenci profilinde yaşanan değişimlerle bağlantılı olarak, öğrencilerin üniversite yaşamına uyum süreçlerini gözden geçirme çalışmaları kapsamında kullanılan ölçme araçlarının yeniden gözden geçirilmesinin ya da yeni ölçme araçları geliştirilmesinin önemli olduğu açıktır. Bu kapsamda, birinci sınıf öğrencilerinin üniversite yaşamına uyum düzeylerini belirlemeyi amaçlayan ölçme araçları gözden geçirildiğinde, özellikle birinci sınıf öğrencilerinin üniversite yaşamına uyumlarını akademik, sosyal, kişiselduygusal ve kurumsal bakış açısı temelinde, çok boyutlu ele alabilecek ve alanyazındaki çalışmaların çeşitlilik ve derinlik kazanmasına yardımcı olabilecek ölçme araçlarının sınırlılığı dikkati çekmektedir. Nitekim, Türkiye'de üniversiteye uyumu ele alan araştırmalarda sıklıkla Üniversiteye Uyum Ölçeği (Akbalık, 1997), Üniversite Yaşamı Ölçeği (Aladağ, Kağnıcı, Tuna ve Tezer, 2003) ve Üniversite Yaşamına Uyum Ölçeği (Aslan, 2015) olarak adlandırılan ölçme araçlarının kullanıldığı gözlemlenmektedir. Yakından incelendiğinde, sözü edilen ölçme araçlarının üniversiteye uyumu, akademik ve sosyal uyum dışında, birbirinden farklı boyutlar temelinde ele aldıkları ve kurumsal uyuma yönelmedikleri görülmektedir. Bu noktada, günümüzde gerçekleştirilen uyum çalışmalarının büyük bir çoğunluğunda ise üniversiteye uyumun dört boyutlu bir bakış açısı ile ele alındığı göz ardı edilmemelidir. Dolayısıyla, bu çalışma kapsamında geliştirilen Üniversiteye Uyum Ölçeğinin, güncel alanyazın temelinde ele alınan dört temel uyum boyutunu kapsaması nedeniyle, birinci sınıf öğrencilerinin üniversite yaşamına uyum düzeylerinin belirlenmesine yönelik çalışmaların artmasına ve çeşitlenmesine katkı sağlayacağı öngörülmektedir. Bu bilgiler 1şığında, bu çalışmada, üniversitede öğrenim gören birinci sınıf öğrencilerinin üniversiteye uyum düzeylerini akademik, sosyal, kişiselduygusal ve kurumsal boyutları ile ele alan bir ölçme aracının geliştirilmesi ve psikometrik özelliklerinin incelenmesi amaçlanmaktadır.

\section{Yöntem}

\section{Çalışma Grupları}

Bu çalışmada, Üniversiteye Uyum Ölçeğinin yapı geçerliğini incelemek üzere iki farklı çalışma grubu oluşturulmuştur. Açıklayıcı faktör analizi için oluşturulan birinci çalışma grubu, bir devlet üniversitesinin altı fakültesinde (Eğitim, İktisadi ve İdari Bilimler, Mühendislik, FenEdebiyat, İletişim ve Eczacılık) yer alan bölümlerde öğrenim gören 712 birinci sınıf öğrencisinden oluşmaktadır. Birinci çalışma grubunun 430'u (\% 60.4) kadın ve 282'si (\% 39.6) erkek öğrencilerden oluşmaktadır. ÜUÖ’nün yapı geçerliği kapsamında gerçekleştirilen doğrulayıcı faktör analizi için oluşturulan ikinci çalışma grubu ise aynı üniversitedeki sözü edilen fakültelerin farklı bölümlerinde yer alan 418 birinci sınıf öğrencisini kapsamaktadır. 
İkinci çalışma grubunun 242'si (\% 57.9) kadın ve 176'sı (\% 42.1) erkek öğrencilerden oluşmaktadır.

Çalışma gruplarının belirlenmesi ile ilgili süreçte öncelikle ilgili üniversite bünyesindeki fakülteler arasından bulundukları yerleşkenin özellikleri, bölümlerin öğrenim yılı, öğrenci ve öğretim üyesi sayıs1, kız ve erkek öğrenci oranı gibi belirlenen temel ölçütleri karşılayan altı fakülte (Eğitim, İktisadi ve İdari Bilimler, Mühendislik, Fen-Edebiyat, İletişim ve Eczacılık) belirlenerek, ilk olarak amaçlı örneklem seçimi gerçekleştirilmiştir. Ardından, küme örnekleme yöntemi kapsamında ilgili 6 fakültenin tüm bölümlerindeki birinci sınıf öğrencileri örnekleme alınmış ve bölümler seçkisiz olarak belirlenerek iki gruba ayrılmıştır. Belirlenen fakülteler bünyesinde zorunlu "yabancı dil hazırlık programı" bulunan bölümler çalışmanın dışında bırakılarak, öğrencileri doğrudan birinci sınıfta öğrenim görmeye başlayan bölümler çalışma gruplarına dâhil edilmiştir.

\section{Veri Toplama Araçları}

\section{Kişisel bilgi formu}

Çalışma gruplarının demografik özelliklerinin uygun şekilde tanımlanması amacıyla katılımcıları betimleyen cinsiyet ve öğrenim görülen bölüm gibi temel bilgiler, araştırmacılar tarafindan hazırlanan soru formu ile elde edilmiştir.

\section{Üniversiteye uyum ölçeği}

Bu çalışma kapsamında psikometrik özellikleri incelenen Üniversiteye Uyum Ölçeği (ÜUÖ), genç-yetişkinlik döneminde yer alan öğrencilerin üniversite yaşamına uyum düzeylerini ölçmek amaciyla geliştirilmiştir.

\section{ÜUÖ’nün geliştirilmesi}

Üniversiteye uyum ölçeğinin geliştirilmesi sürecinde öncelikle konuyla ilgili kapsamlı bir alanyazın incelemesi yapılmış ve yurtiçi çalışmalarda kullanılan Üniversiteye Uyum Ölçeği (Akbalık, 1997), Üniversite Yaşamı Ölçeği (Aladağ vd., 2003) ile yurt dışı çalışmalarda sıklıkla ele alınan Student Adaptation to College Questionnaire (SACQ; Baker ve Siryk, 1984) gibi ölçme araçları incelenmiştir. Bununla birlikte, Sevinç ve Gizir (2014) tarafindan üniversite birinci sınıf öğrencilerinin bakış açılarından üniversiteye uyumu olumsuz etkileyen faktörlerin incelendiği ve nitel araştırma yöntemi kullanılarak yürütülen çalışmanın öğrenci görüşlerinden oluşan verileri detaylı bir şekilde yeniden gözden geçirilmiştir. Bu kapsamda, özellikle Sevinç ve Gizir'in (2014) çalışmasında öğrenci gözlem ve görüşlerinden yararlanılarak ortaya çıkan bulgular temelinde ve alanyazında çeşitli çalışmalarda sıklıkla incelenen dört temel uyum boyutu dikkate alınarak 92 maddelik bir ölçek taslağı oluşturulmuştur. Bu taslak formda akademik uyum, sosyal uyum, kişisel-duygusal uyum ve kurumsal uyum olarak öngörülen her bir alt boyut çerçevesinde üniversite öğrencilerinin o boyuta özgü deneyimlerini anlamaya yönelik çeşitli maddelere yer verilmiştir. Hazırlanan taslak form, uzman görüşü almak amacıyla bir devlet üniversitesinin, Eğitim Bilimleri Bölümünde görev yapmakta olan üç öğretim üyesi ile üç doktora öğrencisinin incelemesine sunulmuştur.

Taslak form, ilgili uzmanların dil, içerik ve kapsam açısından sundukları geribildirim, düzeltme ve öneriler doğrultusunda 79 maddeye indirilmiştir. Bir sonraki aşamada ise oluşturulan taslak form, 30 üniversite öğrencisine uygulanmış ve bu öğrencilerden anlaşılmayan 
ve net olmadığını düşündükleri ifadeleri belirtmeleri istenmiştir. Öğrencilerden gelen geri bildirimler çerçevesinde yapılan düzenlemeler sonucunda son şeklini alan ölçek, kullanıma hazır hale getirilmiştir.

\section{ÜUÖ’nün genel özellikleri}

Geliştirilen ölçeğin sırasıyla akademik uyum (20 madde), sosyal uyum (20 madde), kişiselduygusal uyum (19 madde) ve kurumsal uyum (20 madde) olarak adlandırılan dört boyuttan oluşması planlanmıştır. Akademik uyum, öğrencilerin öğrenim gördükleri bölümle ilgili akademik yükümlülükleri yerine getirebilmeyi ve akademik çevreye yönelik memnuniyeti betimlemektedir. Bu faktöre ilişkin örnek madde: "akademik deneyimlerim bölümüme olan ilgimi giderek arttırıyor" (madde 5) şeklindedir. Sosyal uyum boyutu, öğrencilerin üniversitedeki arkadaş ilişkilerini, yerleşkedeki sosyal yaşama katılımı ve sosyal yaşamdan doyum almayı ifade etmektedir. $\mathrm{Bu}$ faktöre yönelik örnek madde: "üniversitedeki arkadaşlarımla ilişkilerim oldukça iyidir" şeklindedir (madde 2). Kişisel-duygusal uyum boyutu, öğrencilerin öznel duygu-durumlarını kapsamaktadır. Bu faktör için örnek madde: "son günlerde içimden hiçbir şey yapmak gelmiyor" şeklindedir (madde 7). Kurumsal uyum boyutu ise öğrencilerin öğrenim gördükleri kurum (üniversite) memnuniyetleri ve kuruma aidiyetlerini ifade etmektedir. Bu faktöre ilişkin örnek madde: "bu üniversiteyi seçmekle doğru bir karar verdiğimden emin değilim" şeklindedir (madde 4). Likert tipi ölçekteki her bir maddeye verilecek yanıtlar "bana hiç uygun değil (1)" ile "bana tamamen uygun (7)" arasında derecelenmekte olup, ölçekten alınan puanların yüksek olmasının, öğrencilerin üniversiteye uyum düzeylerinin yüksekliğine işaret etmesi öngörülmüştür.

\section{İşlem}

Bu çalışmanın verileri, bir kamu üniversitesi bünyesindeki Eczacılık, Eğitim, Fen-Edebiyat, İktisadi ve İdari Bilimler, İletişim ve Mühendislik Fakültelerinin farklı bölümlerinde öğrenim gören birinci sınıf öğrencilerine uygulanan ÜUO-1 (birinci grup için 79 maddelik form) ve ÜUÖ-2 (ikinci grup için 45 maddelik form) ile elde edilmiştir. Öğrencilerin bu çalışmaya katılım konusundaki gönüllüğü esas alınarak uygulamalar sınıf ortamında gerçekleştirilmiştir. Uygulama öncesinde, ilgili Üniversite Rektörlüğünden ve bölüm başkanlıklarından gerekli izinler alınmıştır. Uygulama sürecinde, temel yönergeler tüm öğrencilere standart bir şekilde açıklanmıştır. Uygulamalar yaklaşık olarak 15-20 dakika sürmüştür.

\section{Bulgular}

\section{ÜUÖ'nün Geçerliğinin İncelenmesi}

Geçerlik çalışmaları kapsamında ÜUÖ'nün yapı geçerliğini incelemek amacıyla açıklayıcı ve doğrulayıcı faktör analizi yöntemlerinden yararlanılmıştır.

\section{Açıklayıcı faktör analizi sonuçları}

ÜUÖ’nün faktör yapısını incelemek üzere ilk olarak Kaiser-Meyer-Olkin (KMO) ve Barlett's Küresellik Testi gerçekleştirilmiştir. Elde edilen veriler kapsamında ölçme aracının KMO değeri .938 olarak belirlenmiş ve Barlett's Küresellik Testi sonucu da ölçekten elde edilen verilerin istatistiksel açıdan anlamlı olduğunu göstermiştir $\left(\chi^{2}=14864.154 ; \mathrm{p}<.01\right)$. Bu sonuçlar, ölçek 
verilerinin çok değişkenli bir yapıda normal bir dağılım sergilediğini ve örneklem büyüklüğünün açıklayıcı faktör analizi için yeterli olduğu göstermiştir.

Ardından, ÜUÖ'deki faktör ve madde sayılarının belirlenebilmesi için birinci çalışma grubundan elde edilen verilere açıklayıcı faktör analizi (AFA) temelinde varimax eksen döndürme yöntemi ile temel bileşenler analizi uygulanmıştır. $\mathrm{Bu}$ çalışma kapsamında geliştirilen ÜUÖ’nün faktör yapısının incelenmesi sürecinde, Kline'nın (2010) ölçek geliştirme araştırmaları için önerdiği temel ölçütler çerçevesinde bir faktöre yüklenen madde sayısı en az beş olacak biçimde faktör yük değeri en yüksek maddeler belirlenmiş ve faktör yük değeri .50 'den düşük olan maddeler ÜUÖ'den çıkarılmıştır. Bununla birlikte, kuramsal ve kavramsal netlik oluşturmak adına birden fazla faktöre yüklenebilen maddeler ölçekten çıkarılmıştır.

$\mathrm{Bu}$ bilgiler 1şı̆̆ında gerçekleştirilen analiz çerçevesinde elde edilen bulgular detaylı bir şekilde incelenerek ölçeğin faktör yapısı belirlenmiştir. Buna göre AFA sonucunda, ölçeğin özdeğeri 1'den büyük dört faktörlü bir yapı sergilediği ve toplam varyansın \% 48.870'ini açıkladığı gözlemlenmiştir. ÜUÖ'nün açıklayıcı faktör analizi ile elde edilen Öz Değerler Grafiği Şekil 1'de verilmektedir. Ayrıca, ÜUÖ'nün faktör yapısı, faktörler içinde yer alan maddelerin faktör yükleri ve madde analizine göre elde edilen madde-toplam korelasyonları Tablo 1'de sunulmaktadır.

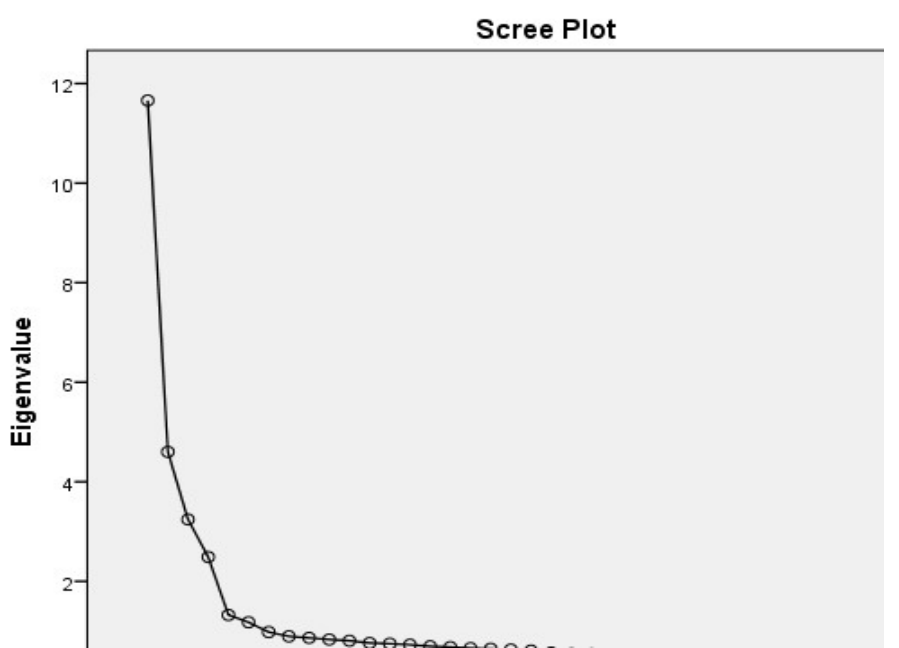

\section{Şekil 1. ÜUÖ’nün Açıklayıcı Faktör Analizi Öz Değerler Grafiği}

Tablo 1 incelendiğinde, Faktör 1'de (akademik uyum) yer alan 12 maddenin $(1,5,9,13$, 17, 21, 25, 29, 34, 38, 43, 45) faktör yükleri .574 ile .792 arasında; Faktör 2' de (sosyal uyum) yer alan 13 maddenin $(2,6,10,14,18,22,26,30,31,35,39,40,44)$ faktör yükleri .500 ile .711 arasında; Faktör 3'te (kurumsal uyum) yer alan 10 maddenin $(4,8,12,16,20,24,28,33,37$, 42) faktör yükleri .595 ile .802 arasında ve son olarak Faktör 4 'te (kişisel-duygusal uyum) yer alan 10 maddenin $(3,7,11,15,19,23,27,32,36,41)$ faktör yükleri .572 ile .789 arasında değişmektedir. Madde toplam korelasyonları temelinde incelendiğinde ise maddeler için elde edilen değerlerin yüksek ve pozitif değerler taşıdığı görülmektedir. Dolayısıyla, AFA sonucunda elde edilen bu bulgular, ÜUÖ'de yer alan 45 maddenin öğrencilerin üniversiteye uyum düzeylerini belirlenen dört faktör temelinde ölçtüğüne ve ölçeğin yapı geçerliğinin bulunduğuna işaret etmektedir. 
Tablo 1. ÜUÖ Maddelerinin Faktör Yükleri, Ortak Faktör Varyansları, Madde Toplam Korelasyonları, Aritmetik Ortalama ve Standart Sapmaları (N=712)

\begin{tabular}{|c|c|c|c|c|c|c|c|c|c|}
\hline \multirow{2}{*}{\multicolumn{2}{|c|}{$\begin{array}{l}\text { Faktörler } \\
\text { ve } \\
\text { Maddeler }\end{array}$}} & \multicolumn{4}{|c|}{ Faktör Yükleri } & \multirow{2}{*}{$\begin{array}{c}\text { Ortak } \\
\text { Varyans }\end{array}$} & \multirow{2}{*}{$\begin{array}{c}\text { Madde } \\
\text { Toplam } \\
\text { Korelasyon } \\
\end{array}$} & \multirow[b]{2}{*}{$\bar{X}$} & \multirow[b]{2}{*}{ SS } \\
\hline & & F1 & F2 & F3 & F4 & & & & \\
\hline \multirow{12}{*}{ 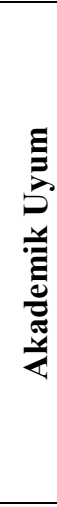 } & M17 & .792 & & & & .660 & .744 & 3.84 & 1.93 \\
\hline & M38 & .753 & & & & .599 & .698 & 4.06 & 1.88 \\
\hline & M34 & .728 & & & & .550 & .658 & 4.24 & 1.89 \\
\hline & M1 & .694 & & & & .490 & .600 & 3.85 & 2.02 \\
\hline & M13 & .693 & & & & .502 & .623 & 3.59 & 1.99 \\
\hline & M29 & .680 & & & & .505 & .641 & 3.69 & 1.83 \\
\hline & M43 & .677 & & & & .474 & .604 & 3.82 & 1.84 \\
\hline & M9 & .671 & & & & .536 & .670 & 3.84 & 1.79 \\
\hline & M25 & .589 & & & & .426 & .593 & 4.47 & 2.02 \\
\hline & M21 & .584 & & & & .403 & .576 & 3.53 & 2.00 \\
\hline & M5 & .580 & & & & .408 & .579 & 4.08 & 2.05 \\
\hline & M45 & .574 & & & & .379 & .549 & 4.10 & 1.82 \\
\hline \multirow{13}{*}{ 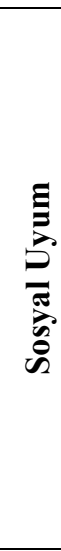 } & M2 & & .711 & & & .546 & .659 & 4.68 & 1.82 \\
\hline & M30 & & .707 & & & .513 & .617 & 5.31 & 1.88 \\
\hline & M10 & & .673 & & & .503 & .629 & 4.47 & 1.95 \\
\hline & M18 & & .636 & & & .489 & .612 & 4.44 & 1.99 \\
\hline & M35 & & .632 & & & .403 & .516 & 4.75 & 2.11 \\
\hline & M22 & & .620 & & & .430 & .574 & 4.38 & 1.88 \\
\hline & M26 & & .610 & & & .380 & .511 & 3.79 & 2.10 \\
\hline & M31 & & .558 & & & .348 & .500 & 3.89 & 2.05 \\
\hline & M6 & & .556 & & & .335 & .505 & 5.52 & 1.88 \\
\hline & M44 & & .555 & & & .425 & .550 & 4.03 & 2.06 \\
\hline & M14 & & .539 & & & .329 & .472 & 5.48 & 1.97 \\
\hline & M39 & & .508 & & & .342 & .503 & 5.19 & 1.99 \\
\hline & M40 & & .500 & & & .351 & .496 & 5.11 & 2.02 \\
\hline \multirow{10}{*}{ 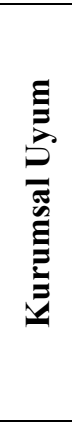 } & M28 & & & .802 & & .703 & .766 & 4.18 & 2.34 \\
\hline & M8 & & & .747 & & .584 & .659 & 3.67 & 2.36 \\
\hline & M20 & & & .746 & & .688 & .767 & 4.08 & 2.05 \\
\hline & M37 & & & .673 & & .634 & .723 & 4.25 & 2.04 \\
\hline & M12 & & & .666 & & .542 & .645 & 3.99 & 2.15 \\
\hline & M33 & & & .651 & & .512 & .643 & 4.84 & 2.07 \\
\hline & M42 & & & .645 & & .567 & .681 & 4.15 & 2.16 \\
\hline & M16 & & & .628 & & .504 & .632 & 4.57 & 2.16 \\
\hline & M24 & & & .603 & & .428 & .570 & 5.14 & 2.08 \\
\hline & M4 & & & .595 & & .471 & .611 & 4.16 & 2.20 \\
\hline \multirow{10}{*}{ 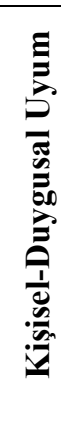 } & M27 & & & & .789 & .647 & .733 & 4.24 & 2.19 \\
\hline & M36 & & & & .729 & .552 & .662 & 3.81 & 2.16 \\
\hline & M32 & & & & .721 & .566 & .673 & 4.88 & 2.11 \\
\hline & M3 & & & & .710 & .536 & .655 & 4.72 & 2.15 \\
\hline & M19 & & & & .699 & .515 & .627 & 4.73 & 2.29 \\
\hline & M23 & & & & .680 & .507 & .618 & 4.51 & 2.09 \\
\hline & M15 & & & & .670 & .467 & .599 & 3.90 & 2.23 \\
\hline & M11 & & & & .658 & .452 & .585 & 4.81 & 2.07 \\
\hline & M41 & & & & .615 & .395 & .541 & 4.46 & 2.22 \\
\hline & M7 & & & & .572 & .396 & .535 & 4.01 & 2.31 \\
\hline \multicolumn{2}{|c|}{ Özdeğerler } & 11.66 & 4.60 & 4.24 & 2.49 & - & - & - & - \\
\hline \multicolumn{2}{|c|}{ Varyans \% } & 25.91 & 10.22 & 7.21 & 5.53 & - & - & - & - \\
\hline \multicolumn{2}{|c|}{$\alpha$} & .90 & .87 & .91 & .89 & - & - & - & - \\
\hline
\end{tabular}




\section{Doğrulayıcı faktör analizi sonuçlart}

Bu çalışmada ÜUÖ’nün faktör yapısını yeniden sınamak ve yapı geçerliliğini doğrulamak amacıyla ikinci çalışma grubundan elde edilen veriler üzerinden doğrulayıcı faktör analizi (DFA) gerçekleştirilmiştir. Bu doğrultuda, geliştirilen ÜUÖ’nün kuramsal altyapısını oluşturan ve AFA sonuçlarına göre 45 madde aracılığıyla dört faktörden oluştuğu belirlenen ölçme modeli başlangıç noktası olarak ele alınarak ilgili maddelerin yer aldığı faktörler ve faktör özellikleri yeniden sınanmıştır.

DFA aşamasında da, Kline'nın (2010) belirttiği ve açıklayıcı faktör analizinde göz önünde bulundurulan temel ölçütler dikkate alınmıştır. Buna göre, bir faktöre yüklenen madde sayısının en az beş olması öngörülmüştür. İkinci olarak, hem kuramsal ve hem de istatistiksel açıdan temel örüntüleri belirlenmiş bir ölçme modelinin yeniden sınandığı varsayımıyla, bir faktör içerisinde en yüksek Lambda $(\lambda \geq .50)$, çoklu korelasyonun karesi $\left(\mathrm{R}^{2} \geq .30\right)$ ve $t(t \geq 2)$ ölçüm değerlerine sahip olan maddeler seçilmiştir.

Bununla birlikte, DFA sürecinde, yapı geçerliği sınanan ölçme modelinin ikinci çalışma grubundan elde edilen veriye uygunluğunu (model fit) incelemek için ölçek geliştirme çalışmalarında sıkça kullanılan model uyum ölçütleri dikkate alınmıştır. Bu ölçütler içinde öncelikli olarak yer alan ki kare $\left(\chi^{2}\right)$, önemli bir uyum ölçütü olmakla birlikte, örneklem sayısının 200'ün üzerinde olduğu durumlarda istatistiksel açıdan güvenilir sonuçlar elde etme konusunda sıkıntılar oluşabileceği vurgulanmaktadır (Schumacker ve Lomax, 2010). Bu nedenle, yüksek örneklem sayısına ulaşıldığı durumlarda, $\chi^{2} / s d$ oranının 2'nin altında olmasının ölçme modelinin uygunluğu açısından oldukça yeterli bir gösterge olacağı belirtilmektedir (Kline, 1998). Bununla birlikte, öngörülen ÜUÖ modelinin, oluşturulan veriye uygunluğunu sinamak üzere GFI (Goodness-of-fit index), AGFI (Adjusted goodness-of-fit index), CFI (Comparative fit index), NFI (Normed fit index), NNFI (Non-normed fit index), IFI (Incremental fit index), RFI (Relative fit index), SRMR (Standardized root mean square residual) ve RMSEA (Root mean squared error of approximation) gibi DFA çalışmalarda yer alan model uyum ölçütleri de kullanılmıştır. Öngörülen ölçme modelinin geçerliğinin onanması için CFI, GFI, AGFI, NFI, NNFI, IFI ve RFI değerleri .90 üzerinde, SRMR ve RMSEA değerleri .05 altında olmalıdır (Schumacker ve Lomax, 2010).

Tablo 2'de, DFA üzerinden elde edilen, maddelerin standardize edilmiş Lambda, $t$ ve $\mathrm{R}^{2}$ değerleri verilmektedir. Buna göre, Lambda açısından ele alındığında faktör yüklerinin .54 ile .80 arasında, $\mathrm{R}^{2}$ değerlerinin ise ile .30 ile .64 arasında değiştiği gözlenmektedir. Ayrıca elde edilen bütün değerler $(t>2 ; \mathrm{p}<.01)$ istatistiksel açıdan anlamlıdır. Dolayısıyla elde edilen bu değerler, maddelerin faktör yüklerinin istatistiksel açıdan yeterli düzeyde olduğunu göstermektedir. Bununla birlikte, DFA sonucunda sınanan dört faktörlü ÜUÖ ölçüm modeli uyum ölçütleri açısından incelendiğinde, $\chi^{2}{ }_{(903)}=1720.70, \chi^{2} / s d=1.91$, RMSEA $=.047$, SRMR $=.051, \mathrm{GFI}=.92, \mathrm{AGFI}=.90, \mathrm{CFI}=.98, \mathrm{NFI}=.95, \mathrm{NNFI}=.97, \mathrm{IFI}=.98$ ve $\mathrm{RFI}=.94$ olarak hesaplanmıştır. Uyum ölçütlerinden elde edilen bu değerler, DFA ile yeniden sınanan 45 maddelik üniversiteye uyum ölçeğin yapı geçerliğinin bulunduğunu göstermektedir. 
Tablo 2. ÜUÖ Maddelerinin Standardize Edilmiş Lambda, $t$ ve $\mathbf{R}^{2}$ Değerleri ( $\mathbf{N}=418)$

\begin{tabular}{|c|c|c|c|c|c|c|c|}
\hline \multicolumn{2}{|c|}{$\begin{array}{c}\text { Faktörler ve } \\
\text { Maddeler }\end{array}$} & $\lambda$ & $t$ & $\mathbf{R}^{2}$ & $\begin{array}{c}\text { Madde } \\
\text { Toplam } \\
\text { Korelasyonu }\end{array}$ & $\bar{X}$ & $S S$ \\
\hline \multirow{12}{*}{ 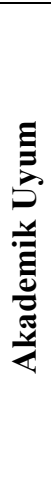 } & M1 & .71 & 16.18 & .51 & .680 & 3.95 & 1.57 \\
\hline & M5 & .58 & 12.27 & .33 & .517 & 4.26 & 1.95 \\
\hline & M9 & .71 & 16.34 & .51 & .666 & 3.78 & 1.80 \\
\hline & M13 & .63 & 13.85 & .40 & .610 & 3.45 & 1.82 \\
\hline & M17 & .77 & 18.17 & .60 & .740 & 3.83 & 1.79 \\
\hline & M21 & .67 & 15.14 & .45 & .645 & 3.62 & 1.88 \\
\hline & M25 & .71 & 16.23 & .51 & .688 & 3.39 & 1.92 \\
\hline & M29 & .72 & 16.58 & .52 & .707 & 3.61 & 1.72 \\
\hline & M34 & .69 & 15.59 & .48 & .709 & 4.15 & 1.77 \\
\hline & M38 & .67 & 14.95 & .45 & .706 & 3.91 & 1.79 \\
\hline & M43 & .68 & 15.26 & .46 & .695 & 3.54 & 1.74 \\
\hline & M45 & .74 & 17.15 & .56 & .666 & 3.91 & 1.85 \\
\hline \multirow{13}{*}{ 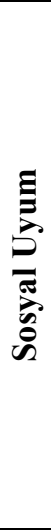 } & M2 & .63 & 12.90 & .39 & .485 & 4.95 & 1.88 \\
\hline & M6 & .59 & 12.93 & .35 & .563 & 5.79 & 1.79 \\
\hline & M10 & .65 & 14.22 & .42 & .597 & 4.64 & 1.87 \\
\hline & M14 & .54 & 11.73 & .30 & .499 & 5.28 & 1.99 \\
\hline & M18 & .68 & 14.84 & .46 & .573 & 4.17 & 1.85 \\
\hline & M22 & .56 & 11.91 & .31 & .498 & 4.11 & 1.84 \\
\hline & M26 & .54 & 11.76 & .30 & .539 & 4.01 & 1.95 \\
\hline & M30 & .65 & 14.10 & .42 & .644 & 5.21 & 1.81 \\
\hline & M31 & .60 & 12.96 & .37 & .541 & 4.21 & 1.87 \\
\hline & M35 & .57 & 12.29 & .32 & .595 & 4.98 & 1.84 \\
\hline & M39 & .57 & 12.37 & .33 & .524 & 5.27 & 1.75 \\
\hline & M40 & .56 & 11.87 & .31 & .471 & 5.25 & 1.84 \\
\hline & M44 & .73 & 16.54 & .53 & .669 & 4.21 & 1.86 \\
\hline \multirow{10}{*}{ 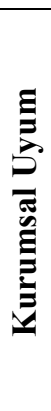 } & M4 & .64 & 14.25 & .41 & .473 & 4.84 & 1.90 \\
\hline & M8 & .66 & 14.66 & .44 & .587 & 3.99 & 2.32 \\
\hline & M12 & .72 & 16.35 & .52 & .671 & 4.57 & 2.01 \\
\hline & M16 & .74 & 17.02 & .54 & .597 & 4.28 & 2.15 \\
\hline & M20 & .78 & 18.22 & .60 & .702 & 4.62 & 2.17 \\
\hline & M24 & .54 & 11.77 & .30 & .652 & 4.33 & 1.95 \\
\hline & M28 & .76 & 17.90 & .58 & .718 & 4.29 & 2.09 \\
\hline & M33 & .75 & 17.58 & .56 & .672 & 4.94 & 2.08 \\
\hline & M37 & .74 & 17.21 & .54 & 690 & 4.05 & 2.10 \\
\hline & M42 & .80 & 19.41 & .64 & .503 & 4.70 & 2.13 \\
\hline \multirow{10}{*}{ 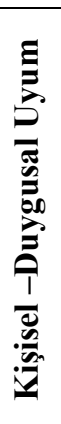 } & M3 & .57 & 12.39 & .33 & .615 & 4.32 & 2.11 \\
\hline & M7 & .62 & 13.61 & .39 & .685 & 3.93 & 2.35 \\
\hline & M11 & .71 & 16.21 & .51 & .719 & 3.90 & 1.95 \\
\hline & M15 & .64 & 13.95 & .41 & .692 & 4.74 & 2.14 \\
\hline & M19 & .75 & 17.56 & .56 & .776 & 4.02 & 2.02 \\
\hline & M23 & .70 & 15.98 & .49 & .457 & 5.14 & 2.01 \\
\hline & M27 & .78 & 18.21 & .61 & .758 & 4.32 & 2.19 \\
\hline & M32 & .70 & 15.67 & .49 & .693 & 4.84 & 2.04 \\
\hline & M36 & .71 & 16.01 & .50 & .684 & 4.11 & 1.85 \\
\hline & M41 & .55 & 11.52 & .30 & .751 & 4.23 & 2.11 \\
\hline
\end{tabular}




\section{ÜUÖ’nin benzer ölçekler geçerliği}

Benzer ölçekler geçerliğinin incelenmesi için 75 üniversite birinci sınıf öğrencisine uygulanan ÜUÖ ile Üniversite Yaşamı Ölçeği (Aladağ, Kağnıcı, Tuna ve Tezer, 2003) arasındaki ilişki incelenmiştir. Yapılan korelasyon analizi sonucunda, iki ölçeğin toplam puanları arasındaki korelasyon değeri .71 olarak belirlenmiştir. Bu bulgu, ÜUÖ’nün benzer ölçekler geçerliği sayıltısını karşıladığı anlamına gelmektedir.

\section{ÜUÖ’nün Güvenirliğinin İncelenmesi}

Geçerlik çalışmalarının yanı sıra ÜUÖ’nün güvenirliğini değerlendirmek üzere ölçeğin iç tutarlık ve test-tekrar test güvenirlikleri sınanmıştır.

\section{$\ddot{U} U \ddot{O}$ 'nün iç tutarlık güvenirliği}

ÜUÖ’nün iç tutarlık güvenirliğini incelemek üzere ikinci çalışma grubundan elde edilen verilerle yapılan analizler sonucunda Cronbach alfa güvenirlik katsayıları akademik uyum için .92 , sosyal uyum için .88, kişisel-duygusal uyum için .91 ve kurumsal uyum için .89 olarak hesaplanmıştır. Ölçeğin bütününe ilişkin Cronbach alfa iç tutarlık katsayısı ise .94 olarak belirlenmiştir. Birinci çalışma grubundan elde edilen veriler incelendiğinde de ÜUÖ’nün yüksek iç tutarlık güvenirliği değerlerine sahip olduğu görülmektedir (bkz. Tablo 5). Bu bulgular, ölçekteki faktörlerin tümünün yüksek düzeyde güvenirliğinin bulunduğunu göstermektedir.

\section{Tablo 5. ÜUÖ’nün İç Tutarlık Güvenirliği}

\begin{tabular}{lcc}
\hline \multicolumn{1}{c}{ Faktörler } & $\begin{array}{c}\text { AFA Grubu } \\
(\mathbf{N = 7 1 2 )}\end{array}$ & $\begin{array}{c}\text { DFA Grubu } \\
(\mathbf{N = 4 1 8 )}\end{array}$ \\
\hline 1. Akademik Uyum & .90 & $\boldsymbol{\alpha}$ \\
2. Sosyal Uyum & .87 & .92 \\
3. Kişisel Uyum & .89 & .88 \\
4. Kurumsal Uyum & .91 & .91 \\
5. Üniversiteye Uyum & .93 & .89 \\
\hline
\end{tabular}

\section{ÜÜ̈'nin test-tekrar test güvenirliği}

ÜUÖ’nin tekrar test güvenirliğinin incelenmesi amacıyla ölçek 71 üniversite birinci sınıf öğrencisine üç hafta arayla yeniden uygulanmıştır. Yapılan analiz sonucunda elde edilen korelasyon değerleri akademik uyum için .86, sosyal uyum için .80, kişisel-duygusal uyum için .76 ve kurumsal uyum için .88 olarak hesaplanmıştır. Ölçeğin tamamına ilişkin korelasyon katsayısı ise .88 olarak saptanmıştır. Bu bulgular, ölçeğin tüm faktörlerinin yüksek düzeyde testtekrar test güvenirliği olduğunu kanıtlamaktadır.

\section{Tartışma ve Sonuç}

$\mathrm{Bu}$ çalışmada, üniversite birinci sınıf öğrencilerin üniversiteye uyum düzeylerinin dört temel boyut çerçevesinde kapsamlı bir şekilde ölçülmesine olanak tanıması amacıyla geliştirilen ÜUÖ'nün geçerlik ve güvenirliği incelenmiştir. Bu kapsamda yapılan açıklayıcı ve doğrulayıcı faktör analizi sonuçları, ÜUÖ’nün yapı geçerliğinin bulunduğunu ve ölçekte yer alan toplam 45 maddenin, "akademik uyum", "sosyal uyum", "kişisel-duygusal uyum" ve "kurumsal uyum" olarak betimlenen dört faktörlü bir yapı oluşturduğunu göstermiştir. Bununla birlikte, ÜUÖ’nün iç tutarlık güvenirliğinin incelenmesi amacıyla yapılan analiz sonuçlarına göre ölçeği oluşturan 
dört faktörün Cronbach alfa güvenirlik katsayıları .88 (sosyal uyum) ile .92 (akademik uyum), test-tekrar test yöntemiyle belirlenen korelasyon katsayıları ise .76 (kişisel-duygusal uyum) ile .88 (kurumsal uyum) arasında değişmektedir. Bu bulgular, ÜUÖ’nün yüksek düzeyde güvenirliğinin bulunduğuna işaret etmektedir. $\mathrm{Bu}$ sonuçlar, yapılan geçerlik ve güvenirlik analizleri sonucunda 45 madde ve dört faktörlü bir yap1 sergilediği belirlenen ÜUÖ’nün, üniversite öğrencilerinin uyum düzeylerini belirlemek amacıyla kullanılabileceğini ortaya koymaktadır.

İlgili alanyazın incelendiğinde, üniversite öğrenimine başlamayla birlikte çok çeşitli stres faktörleriyle karşılaşan üniversite birinci sınıf öğrencilerinin üniversiteye uyum düzeyleriyle ilişkilendirilen çeşitli faktörlerin bulunduğu göze çarpmaktadır. Akademik uyum temelinde gerçekleştirilen çalışmalar ele alındığında, akademik başarı ve motivasyon (Freeman, Anderman ve Jensen, 2007; Meng, Huang, Hou ve Fan, 2015; Wintre ve Bowers, 2007), öğretim elemanlarıyla resmi ve resmi olmayan biçimlerde kurulan ilişkiler (Basow, 2000; Boulter, 2002; Cotten ve Wilson, 2006; Sevinç 2010; Sevinç ve Gizir, 2014), kişilik özellikleri (Chemers, Hu ve Garcia, 2001; Rahat, 2014; Sürücü ve Bacanl1, 2010) ve akademik yaşama ilişkin beklentiler (Jackson, Pancer, Pratt ve Hunsberger, 2000; Krieg, 2013), akademik uyum ile ilişkili en önemli değişkenler olarak nitelendirilmektedir.

$\mathrm{Bu}$ bağlamda, öğrencilerin üniversiteye sosyal uyumlarına ilişkin yapılan çalışmalar incelendiğinde, sosyal destek ağları (Duru, 2008; Murray, Lombardi, Bender ve Gerdes, 2013; Salami, 2011), arkadaş ilişkileri (Buote vd., 2007; Pittman ve Richmond, 2008; Swenson, Nordstrom ve Hiester, 2008), yerleşkedeki ders dış1 etkinliklere katılım (Arola, 2012; Busseri vd., 2010) ve sosyal beceriler (Bohnert, Aikins ve Edidin, 2007) gibi değişkenlerin öğrencilerin sosyal uyumlarıyla ilişkili olarak ele alındığı görülmektedir.

Kişisel-duygusal uyum temelinde yürütülen çalışmalar incelendiğinde ise birinci sınıf öğrencileri açısından evden uzak olma ve bununla bağlantılı olarak ortaya çıkan sınırlı sosyal destek (Tao, Dong, Pratt, Hunsberger ve Pancer, 2000), düşük kendilik değeri ve öz-sayg1 (Mooney, Sherman ve Lo-Presto, 1991), ekonomik zorluklar (Julia ve Veni, 2012; Sevinç, 2010; Sevinç ve Gizir, 2014), baş etme becerilerinin sınırl1lı̆̆ (Chemers vd., 2001; Tuna, 2003; Yalım, 2007), ayrımlaşma ve bireyselleşme temelindeki gelişimsel konular (Ames vd., 2011; Mattanah, Lopez ve Govern, 2011) gibi çeşitli değişkenlerin öğrencilerin yalnızlık, kaygı ve depresyon gibi olumsuz duyguları deneyimlemelerine neden olduğu ve bu durumun büyük oranda kişisel-duygusal uyum çerçevesinde ele alındığı gözlemlenmektedir.

Kurumsal uyum çerçevesinde gerçekleştirilen çalışmalar gözden geçirildiğinde de, öğrencilerin istedikleri bölüm ya da üniversitede öğrenim görmeleri (Özkan ve Y1lmaz, 2010; Sevinç, 2010; Erdoğan, Bekir ve Şanlı, 2005), üniversitede verilen eğitimi değerli ve anlamlı bulmaları (Astin, 1993; Pascarella ve Terenzini, 2005; Kuh ve Hu, 2001), üniversite yaşamına katılım düzeyleri (Astin, 1993; İlhan, Çam ve Çam, 2018; Tinto, 1993), üniversite ile amaç ortaklı̆̆ kurabilmeleri (Baker ve Siryk, 1984), öğretim elemanlarnyla güven ve samimiyete dayalı iletişim kurabilmeleri (Cotten ve Wilson, 2006; Kim ve Sax, 2014; Sevinç, 2010) ile yeni sosyal ve akademik yaşamlarında deneyimledikleri zorluklar (Yıldırım, 2009) temelinde şekillenen faktörlerin kurumsal uyum ile ilişkili olduğu vurgulanmaktadır.

Görüldüğü üzere, üniversite öğrencilerinin akademik, sosyal, kişisel-duygusal ve kurumsal düzeyde uyumları çerçevesinde ele alınan çok çeşitli çalışma alanları bulunmaktadır. 
Bu noktada, sürekli değişen psikososyal özellikleri, gereksinimleri ve problemleri odağında günümüz üniversite öğrencilerinin üniversite yaşamına uyum süreçlerini çok boyutlu ele alan nitelikli ölçme araçlarının geliştirilmesinin önemi açıktır. Bu bakış açısıyla, bu çalışma kapsamında ve güncel alanyazın çerçevesinde geliştirilen Üniversiteye Uyum Ölçeğinin içerdiği madde çeşitliliği ve faktörler temelinde kapsam geçerliğinin bulunduğu düşünülmektedir. Bununla birlikte, ÜUÖ’nün yapı geçerliliği sınanmış dört faktörlü yapısı ve yüksek düzeyde güvenirliği ile günümüz öğrencilerinin üniversiteye uyum düzeylerini belirleme konusunda kullanılabilecek psikometrik özellikleri büyük oranda taşıdığı değerlendirilmektedir.

Steingass ve Sykes (2008), öğrencilerinin akademik, mesleki, kişisel ve sosyal alanlarda gelişerek, başarılı bir şekilde mezun olmalarının, üniversitelerin başlıca amaçlarından birisi olduğunu ifade etmektedir. Bununla birlikte, liseyi bitirir bitirmez üniversite öğrenimine başlamanın genç yetişkinler arasında bir kurala dönüşmeye başladığı günümüzde (Arola, 2012), üniversite yaşamı ve üniversite yaşamına ilişkin deneyimlerin birçok çalışmanın odağı haline geldiği görülmektedir. Bu bilgiler 1şığında, bu çalışmada geçerlik ve güvenirliği sınanan ÜUÖ, üniversite öğrencileriyle yürütülecek uyum çalışmalarında kullanılabilir ve ilgili alanyazın gelişimine önemli katkılar sağlayabilir. Buna ek olarak, üniversiteye uyum temelinde ÜUÖ, yükseköğrenimde okul terki, üniversite öğrencilerinin problem ve gereksinimleri ile baş etme becerileri ve sosyal destek kaynakları gibi çok çeşitli konu alanlarında yürütülecek araştırmalarda kullanılabilir. Ayrıca, ÜUÖ'nün çeşitli araştırmalarda kullanılması temelinde elde edilecek bulgular ile Yükseköğrenimde Psikolojik Danışma ve Rehberlik Hizmetleri başta olmak üzere ilgili uygulama alanlarına katkı sunulabilir. Bu kapsamda ÜUÖ, özellikle gençyetişkinlik gelişim döneminde bulunan öğrencilerin üniversiteye uyumlarına yönelik planlanan önleyici ve gelişimsel çalışmalara önemli bir bakış açısı sağlayabilir ve üniversiteye uyum çerçevesinde yürütülebilecek programların çeşitlendirilmesine yardımcı olabilir.

$\mathrm{Bu}$ çalışma, bir kamu üniversitesi bünyesinde lisans düzeyinde öğrenim görmekte olan öğrenciler ile yapılmıştır. Gelecekte çeşitli vakıf ve kamu üniversitelerini içine alan geniş kapsamlı çalışma gruplarıyla UÜÖ’nün psikometrik yapısının yeniden ele alınmasının önemli katkılar sağlayacağı düşünülmektedir. Benzer şekilde ÜUÖ’nün Türkiye'deki üniversitelerde öğrenim görmekte olan yabancı uyruklu öğrenciler ve yine lisansüstü öğrenciler kapsamında geçerlik ve güvenirliğinin sınanmasının oldukça yararlı olacağı değerlendirilmektedir.

Üniversite Uyum Ölçeğinin Geliştirilmesi: Geçerlik ve Güvenirlik Çalışmaları başlıklı çalışmanın yazım sürecinde bilimsel, etik ve alıntı kurallarına uyulmuş; toplanan veriler üzerinde herhangi bir tahrifat yapılmamış, karşılaşılacak tüm etik ihlallerde "Pamukkale Üniversitesi Eğitim Fakültesi Dergisi Yayın Kurulunun" hiçbir sorumluluğunun olmadığı, tüm sorumluluğun Sorumlu Yazara ait olduğu ve bu çalışmanın herhangi başka bir akademik yayın ortamına değerlendirme için gönderilmemiş olduğunu taahhüt ederim. 


\section{Kaynakça}

Akbalık, F. G. (1997). Bilgilendirme ve grupla psikolojik danışmanın üniversite birinci sınıf ögrencilerinin üniversiteye uyumları üzerine etkisi. Yayınlanmamış doktora tezi, Ankara Üniversitesi, Ankara.

Aladağ, M., Kağnıcı, D. Y., Tuna, M. E. ve Tezer, E. (2003). Üniversite yaşamı ölçeği: Ölçek geliştirme ve yapı geçerliği üzerine bir çalışma. Psikolojik Danışma ve Rehberlik Dergisi, 2(20), 41-47.

Ames, M. E., Pratt, M. W., Pancer, S. M., Wintre, M. G., Polivy, J., Birnie-Lefcovitch, \& S., Adams, (2011). The moderating effects of attachment style on students' experience of a transition to university group facilitation program. Canadian Journal of Behavioural Science, 43(1), 1-12. doi:10.1037/a0020648

Arola, N. (2012). Organized activity involvement across the transition to college: Multiple dimensions predicting adjustment. Unpublished master's thesis, Loyola University, Chicago.

Aslan, S. (2015). Üniversite Yaşamına Uyum Ölçeği'nin geliştirilmesi, Hacettepe Üniversitesi Eğitim Fakültesi Dergisi, 30(4), 132-145.

Astin, A. W. (1993). What matters in college? Four critical years revisited. San Francisco: Jossey-Bass Publishers.

Ayhan, F. (2005). Ege Üniversitesi ögrencilerinin üniversiteye uyum düzeylerinin çeşitli değişsenlere göre incelenmesi. Yayınlanmamış yüksek lisans tezi, Ege Üniversitesi, Sosyal Bilimler Enstitüsü, İzmir.

Awang, M. M., Kutty, F. M., \& Ahmad, A. R. (2014). Perceived social support and well-being: First-year student experience in university. International Education Studies, 7(13), 261-270. doi:10.5539/ies.v7n13p261

Backhaus, A. L. (2009). The college experience: Exploring the relationships among student socioeconomic background, experiences of classism, and adjustment to college. Unpublished doctoral dissertation, University of Nebraska, Nebraska.

Baker, R., \& Siryk, B. (1984). Measuring adjustment to college. Journal of Counseling Psychology, 33, 31-38.

Baker, R. W., \& Siryk B. (1986). Exploratory intervention with a scale measuring adjustment to college. Journal of Counseling Psychology, 33(1), 31-38.

Baker, R., McNeil, O., \& Siryk, B. (1985). Expectation and reality in freshman adjustment to college. Journal of Counseling Psychology, 32, 94-103.

Basow, S. A. (2000). Best and worst professors: Gender patterns in students' choice. Sex Roles, 43, 407417.

Bean, J. P. (1980). Dropouts and turnover: The synthesis and test of a casual model of student attrition. Journal of Research in Higher Education, 12, 155-187.

Bohnert, A. M., Aikins,J. W., \& Edidin, J. (2007). The role of organized activities in facilitating social adaptation across the transition to college. Journal of Adolescent Research, 22(2), 189-208.

Boulter, L. T. (2002). Self-concept as a predictor of college freshman academic adjustment. College Student Journal, 36(2), 234-246. 
Buote, V. M., Pancer, S. M., Pratt, M. W., Adams, G., Birnie-Lefcovith, S., \& Polivy, J. (2007). The importance of friends: Friendship and adjustment among first-year university adjustment. Journal of Adolescent Research, 22(6), 665-689. doi: 10.1177/0743558407306344

Busseri, M. A., Rose-Krasnor, L., Pancer, S. M., Pratt, M. W., Adams, G. R., Birnie-Lefcovitch, S., Polivy, J., \& Wintre, M. G. (2010). A longitudinal study of breadth and intensity of activity involvement and the transition to university. Journal of Research on Adolescence, 21(2), 512-518. doi:10.1111/j.1532-7795.2010.00691.x

Chemers, M., Hu, L., \& Garcia, B. F. (2001). Academic self-efficacy and first year college student performance and adjustment. Journal of Educational Psychology, 93, 55-64.

Clinciu, A. L. (2013). Adaptation and stress for the first year university students. Social and Behavioral Sciences, 78, 718-722. doi: 10.1016/j.sbspro.2013.04.382

Cooke, R., Bewick, B. M., Barkham, M., Bradley, M., \& Audin, K. (2006). Measuring, monitoring and managing the psychological well-being of first year university students. British Journal of Guidance and Counselling, 34(4), 505-517. doi:10.1080/03069880600942624

Cotten, S. R., \& Wilson, B. (2006). Student-faculty interactions: Dynamics and determinants. Journal of Higher Education and Educational Planning, 51(4), 487-519.

Dyson, R., \& Renk, K. (2006). Freshmen adaptation to university life: Depressive symptoms, stress, and coping. Journal of Clinical Psychology, 62(10), 1231-1244.

Duru, E. (2008). The predictive analysis of adjustment difficulties from loneliness, social support, and social connectedness. Educational Sciences: Theory \& Practice, 8(3), 849-856.

Erdoğan, S., Bekir, H. Ş. ve Şanlı, H. S. (2005). Gazi üniversitesi eğitim fakültesi öğrencilerinin ekonomik, sosyal, kültürel uyum sorunlarını etkileyen bazı etmenler. Gazi Üniversitesi Endüstriyel Sanatlar Eğitim Fakültesi Dergisi, 16, 1-13.

Fassig, E. I. (2003). Attachment and resilience as predictors of adjustment to college in college freshmen. Unpublished doctoral dissertation, University of Northern Colorado, Colorado.

Feldt, R. C., Graham, M., \& Dew, D. (2011). Measurement adjustment to college: Construct validity of the student adaptation to college questionnaire. Measurement and Evaluation in Counseling and Development, 44, 9-104. doi:10.1177/0748175611400291

Freeman, T. M., Anderman, L. H., \& Jensen, J. M. (2007). Sense of belonging in college freshmen at the classroom and campus levels. The Journal of Experimental Education, 75, 203-220.

Gall, T. R., Evans, D. R., \& Bellerose, S. (2000). Transition to first-year university: Patterns of change in adjustment across life domains and time. Journal of Social and Clinical Psychology, 19(4), 544-567.

Gizir, C. A. (2014). Üniversite öğrencilerinin psikolojik danışma gereksinimleri üzerine bir çalışma: Mersin Üniversitesi örneği. I. Avrasya Eğitim Araştırmaları Kongresi'nde Sunulan Bildiri (24-26 Nisan 2014), İstanbul Üniversitesi, İstanbul.

Gizir, S. (2019). The sense of classroom belonging among pre-service teachers: Testing a theoretical model. European Journal of Educational Research, 8, 87-97. doi:10.12973/eu-jer.8.1.87

Hersh, M. A., \& Hussong, A. M. (2006). High school drinker typologies predict alcohol involvement and psychosocial adjustment during acclimation to college. Journal of Youth and Adolescence, 5, 738751.

İlhan, E., Çam, Ş. S. ve Çam, Z. (2018). Yükseköğretimde öğrencilerin akademik, sosyal ve kültürel faaliyetlere etkin katılımı. Türk Ĕ̆itim Bilimleri Dergisi, 16(2), 213-234. 
Jackson, L. M., Pancer, S. M., Pratt, M. W., \& Hunsberger, B. (2000). Cognitive complexity of expectations and adjustment to university in the first year. Journal of Adolescent Research, 15, 38-57.

Julia, M., \& Veni, B. (2012). An analysis of the factors affecting students' adjustment at a university in Zimbabwe. International Education Studies, 5(6), 244-250. doi:10.5539/ies.v5n6p244

Katz, S., \& Somers, C. L. (2017). Individual and environmental predictors of college adjustment: Prevention and intervention. Current Psychology, 36(1), 56-65. doi:10.1007/s12144-015-9384-0

Kim, Y. K., \& Sax, L. J. (2011). Are the effects of student-faculty interaction dependent on major? An examination using multi-level modeling. Research in Higher Education, 52(6), 589-615.

Kline, R. B. (1998). Principles and practices of structural equation modeling. New York: The Guilford Press.

Kline, R. B. (2010). Principles and practice of structural equation modeling (3rd ed.). New York: Guilford Press.

Klomegah, R. Y. (2006). Social factors relating to alienation experienced by international students in the United States. College Student Journal, 40(2), 303-315.

Krieg, D. (2013). High expectations for higher education? Perceptions of college and experiences of stress prior to and through the college career. College Student Journal, 47(4), 635-643.

Kuh, G. D., \& Hu, S. (2001). The effects of student-faculty interaction in the 1990s. The Review of Higher Education, 24(3), 309-332.

Lau, L. (2003). Institutional factors affecting student retention. Education, 124, 66-80.

Lidy, K. M., \& Kahn, J. H. (2006). Personality as a predictor of first-semester adjustment to college: The mediational role of perceived social support. Journal of College Counseling, 9(2), 123-134.

Mattanah, J. F., Lopez, F. G., \& Govern, J. M. (2011). The contributions of parental attachment bonds to college student development and adjustment: A meta-analytic review. Journal of Counseling Psychology, 58(4), 565-596. doi:10.1037/a0024635.

Meng, H., Huang, P., Hou, N., \& Fan, J. (2015). Social self-efficacy predicts Chinese college students’ first-year transition: A four-wave longitudinal investigation. Journal of Career Assessment, 23(3), 410-426. doi:10.1177/1069072714547482

Monroe, P. (2009). International encyclopedia of education. (Ed.) New Delhi: Cosmo Publications.

Mooney, S. P., Sherman, M. F., \& Lo-Presto, C. T. (1991). Academic locus of control, self-esteem, and perceived distance from home as predictors of college adjustment. Journal of Counseling and Development, 69(5), 445-448.

Murray, C., Lombardi, A., Bender, F., \& Gerdes, H. (2013). Social support: Main and moderating effects on the relation between financial stress and adjustment among college students with disabilities. Social Psychology of Education, 16(2), 277-295. doi:10.1007/s11218-012-9204-4

Özkan, S. ve Y1lmaz, E. (2010). Üniversite öğrencilerinin üniversite yaşamına uyum durumları (Bandırma örneği). Fırat Sağlık Hizmetleri Dergisi, 5(13), 153-171.

Pascarella, E. T., \& Terenzini, P. T. (2005). How college affects students: Findings and insights from twenty years of research. San Francisco: Jossey-Bass Publishers.

Paul, E. L., \& Brier, S. (2001). Friendsickness in the transition to college: Precollege predictors and college adjustment correlates. Journal of Counseling and Development, 79, 77-89.

Perls, F. S. (1969). Gestalt therapy verbatim. USA: Real People Press. 
Pittman, L.D. \& Richmond, A. (2008). University belonging, friendship quality, and psychological adjustment during the transition to college. The Journal of Experimental Education, 76, 343-362.

Rahat, E. (2014). Benlik kurgusu, sosyal destek, başa çıkma stilleri ve yılmazlığın üniversite yaşamına uyumu yordama güçlerinin incelenmesi. Yayınlanmamış yüksek lisans tezi, Gaziosmanpaşa Üniversitesi, Eğitim Bilimleri Enstitüsü, Tokat.

Rienties, B., Beausaert, S., Grohnert, T., Niemantsverdriet, S., \& Kommers, P. (2011). Understanding academic performance of international students: The role of ethnicity, academic and social integration. Higher Education Quarterly, 63, 685-700. doi:10.1007/s10734-011-9468-1

Salami, S. O. (2011). Psychosocial predictors of adjustment among first year college of education students. US-China Education Review, 8(2), 239-248.

Schumacher, R. E., \& Lomax, R. G. (2010). A beginner's guide to structural equation modeling. New York: Routledge.

Sevinç, S. (2010). Üniversite birinci sinıf öğrencilerinin üniversiteye uyumlarını olumsuz etkileyen faktörlerin incelenmesi. Yayınlanmamış yüksek lisans tezi, Mersin Üniversitesi, Sosyal Bilimler Enstitüsü, Mersin.

Sevinç, S. ve Gizir, C. A. (2014). Üniversite birinci sınıf öğrencilerinin bakış açılarından üniversiteye uyumu olumsuz etkileyen faktörler (Mersin Üniversitesi örneği). Kuram ve Uygulamada Ĕgitim Bilimleri, 14(4), 1285-1308. doi:10.12738/estp.2014.4.2081

Sürücü, M. ve Bacanlı, F. (2010). Üniversiteye uyumun psikolojik dayanıklılık ve demografik değişkenlere göre incelenmesi. Gazi Eğitim Fakültesi Dergisi, 2, 375-396.

Steingass, S, J., \& Sykes, S. (2008). Centralizing advising to improve student outcomes. Peer Review, $10(1), 18-20$.

Swenson, L. M., Nordstrom, A., \& Hiester, M. (2008). The role of peer relationships in adjustment to college. Journal of College Student Development, 49(6), 551-567. doi:10.1353/csd.0.0038

Tao, S., Dong, Q., Pratt, M. W., Hunsberger, B., \& Pancer, S. M. (2000). Social support: Relations to coping and adjustment during the transition to university in the People's Republic of China. Journal of Adolescent Research, 15, 123-144.

Tinto, V. (1993). Leaving college: Rethinking the causes and cures of student attrition. Chicago: The University of Chicago Press.

Tinto, V. (1988). Stages of student departure: Reflections on the longitudinal character of student leaving. Journal of Higher Education, 59(4), 438-455.

Trockel, M. T., Barnes, M. D., \& Egget, D. L. (2000). Health-related variables and academic performance among first-year college students: Implications for sleep and other behavior. Journal of American College Health, 49, 125-38.

Tuna, M., E. (2003). Cross-cultural differences in coping strategies as a predictor of university adjustment of Turkish and U.S students. Unpublished doctoral dissertation, Middle East Technical University, Ankara.

Uslu-Gülşen, F. (2017). Yükseköğretimde okul terkinin değerlendirilmesi. Yayınlanmamış doktora tezi, Eskişehir Osmangazi Üniversitesi, Eğitim Bilimleri Enstitüsü, Eskişehir.

Yalım, D. (2007). First year college adjustment: The role of coping, ego resiliency, optimism and gender. Unpublished master's thesis, Middle East Technical University, Ankara. 
Y1ldirım, O. (2009). A study of adjustment problems of Turkish students studying in dual diploma engineering programs in the U.S.A.: The effects of English language, education differences, \& academic program structure. Unpublished doctoral dissertation, State University of New York, Buffalo.

Wintre, M. G., \& Bowers, C. D. (2007). Predictors of persistence to graduation: Extending a model and data on the transition to university model. Canadian Journal of Behavioural Science, 39, 220-234. 


\section{Extended Abstract}

\section{Introduction}

Adjustment to university is a major life transition for the first-year university students trying to manage successfully. A large body of literature provides evidence for the importance of certain academic, social, personal and institutional factors on students' successful transition to university and their persistence to graduation (Baker, McNeil, \& Siryk, 1985; Clinciu, 2013; Dyson \& Renk, 2006; Freeman, Anderman, \& Jensen, 2007; Gall, Evans, \& Bellerose, 2000; Julia \& Veni, 2012; Pasceralla \& Terenzini, 2005; Tinto, 1993). The concepts of observing and measuring the adjustment levels of university students to university life are also not new to counseling and psychology in Turkey. Some researchers (Akbalık, 1997; Aladağ, Kağnıc1, Tuna, \& Tezer, 2003; Aslan, 2015) have designed a series of psychometrically well-established measures to assess the university adjustment. Although these instruments play a significant role in research studies examining the adjustment levels of university students in Turkey, it is important to develop a new measure representing several dimensions of university adjustment including academic, social, personal/emotional, and institutional domains as proposed in the related literature (Ayhan, 2005; Fassig, 2003; Katz \& Somers, 2017; Lidy \& Kahn, 2006; Rahat, 2014; Salami, 2011; Tuna, 2003; Yalım, 2007). As a complex and multifaceted construct, adjustment to university life involves many factors (Baker \& Siryk, 1984) and a new multidimensional measure of adjustment may provide significant information for university staff interested in student well-being at campus. With this background, the purpose of the present study is to develop and examine the psychometric properties of a new instrument namely, the University Adjustment Scale (UAS) developed to assess the adjustment levels of Turkish university students.

\section{Method}

The participants of the study consisted of 712 (430 female, 282 male for exploratory factor analysis) and 418 (242 female, 176 male for confirmatory factor analysis) first-year undergraduate students enrolled in various faculties of a state university in Turkey. In the development process of the scale, firstly the researchers constructed 92 items under the four factorial structure of the UAS based on a review of the literature related to university adjustment scales (Akbalık, 1997; Aladağ, Kağnıcı, Tuna ve Tezer, 2003; Baker ve Siryk, 1984) and an extensive analysis of a qualitative study aimed at deeply exploring the factors affecting the adjustment of university students (Sevinç \& Gizir, 2014). Then, six researchers reexamined the written items of the scale and 79 items were admitted for using to assess the adjustment levels of university students through the feedbacks. Finally, the feedbacks of a pilot sample composed of 30 first-year university students were examined to decide the concrete expressions of the items in the scale. Of these items, 20 were written to represent the component of academic adjustment, 20 for social adjustment, 19 for personal-emotional adjustment, and 20 for institutional adjustment. The scale was measured on a 7-point scale from "completely agree" (7 points) to "completely disagree" (1 point). High scores obtained from the UAS indicates the higher level of adjustment to university on academic, social, personal and institutional domains. The construct validity of the scale was examined by using exploratory and confirmatory factor analyses. Moreover, internal consistency and test-retest analyses were conducted to assess the reliability of the scale. 


\section{Results}

The result of the exploratory factor analysis (EFA) indicated that the University Adjustment Scale (UAS) constituted from 45 items and four factors including, "academic adjustment" (12 items), "social adjustment" (13 items), "personal-emotional adjustment" (10 items), and "institutional adjustment" (10 items). The confirmatory factor analysis (CFA) result for the proven model of the UAS also revealed the following fit indexes: $\chi^{2}{ }_{(903)}=1720.70, \chi^{2} / s d=$ $1.91, \mathrm{RMSEA}=.047, \mathrm{SRMR}=.051, \mathrm{GFI}=.92, \mathrm{AGFI}=.90, \mathrm{CFI}=.98, \mathrm{NFI}=.95, \mathrm{NNFI}=.97$, IFI $=.98$, and RFI $=.94$. The scores obtained from the fit indexes were seen as highly acceptable and the UAS demonstrated very good psychometric structure. The UAS scores were also evaluated in relation to the University Life Scale (ULS; Aladağ et al., 2003) scores in order to assess concurrent validity. The calculated Pearson correlation result indicated a high correlation between UAS and ULS $(\mathrm{r}=0.71, \mathrm{p}<.001)$. The reliability analysis also revealed that Cronbach alpha internal consistency coefficients of the factors were .92 for academic adjustment, .88 for social adjustment, .91 for personal-emotional adjustment, and .89 for institutional adjustment. The test-retests (three weeks interval) reliability coefficients of the factors were also acceptable including, $.86, .80, .76, .88$, respectively. These results showed that the reliability indications of the UAS was also very satisfactory.

\section{Discussion}

The purpose of the study was to investigate the psychometric properties of the newly developed University Adjustment Scale using a sample of first-year university students from a public university in Turkey. All the findings of the study indicated that the UAS has a very good psychometric properties for using to assess the university adjustment levels of first-year university students in terms of academic, social, personal-emotional and institutional dimensions. Furthermore, it is claimed that the UAS can be easily and confidently used in the practice of college counseling research in order to develop preventive and developmental programs for a smooth transition of newcomers to university life. On the other hand, this study is the first to examine the psychometric properties of the UAS. Further studies should be done to investigate the strength of these indications on other cohorts of university students including international students, graduate students and in other universities in Turkey. 